\subsection{Réduction de $\mathrm{Ni}^{+2}$ en présence de complexants}

La réduction électrochimique de $\mathrm{Ni}^{+2}$ complexé par divers acides carboxyliques a été étudiée dans une cellule à cathode volumique de type PU 20 ppi. L'aire cathodique totale était de $0,26 \mathrm{~m}^{2}$ pour un volume de réacteur de $1,910^{-3} \mathrm{~m}^{3}$, ce qui correspond à un rapport aire cathodique/ volume du réacteur de $140 \mathrm{~m}^{-1}$. L'électrolyte est une solution $0,1 \mathrm{M}$ de $\mathrm{Na}_{2} \mathrm{SO}_{4}$ à $\mathrm{pH}$ 6 , contenant environ $100 \mathrm{ppm}$ de $\mathrm{Ni}^{+2}$ et $1 \%$ de divers acides carboxyliques. La vitesse linéaire de l'électrolyte percolant les électrodes est de $8 \cdot 10^{-3} \mathrm{~m} \mathrm{~s}^{-1}$. Une bonne agitation est assurée par de l'air introduit en bas de la cellule. Les résultats obtenus sont présentés sur la fig 7. On constate qu'en prolongeant la durée de la réduction, on peut atteindre une concentration en $\mathrm{Ni}^{+2}$ inférieure à $2 \mathrm{ppm}$ en pré- sence de tous les acides testés, à l'exception de l'acide citrique. La spéciation du Ni en présence d'acide citrique est actuellement étudiée par polarographie et au moyen d'une électrode spécifique.

Une partie de ce travail a été subventionnée par la Commission pour l'encouragement de la recherche scientifique (crédit CERS No. 1762.1).

Reçu le 20 janvier 1992

[1] Nomenclature: $I$ courant limite [A], $n$ : nombre d'électrons échangés, $F$ : constante de Faraday $\left[\mathrm{A} \mathrm{s}^{-1}\right], A$ : aire de l'électrode $\left[\mathrm{m}^{2}\right], K_{\mathrm{d}}$ coefficient de transfert de matière $\left[\mathrm{ms}^{-1}\right], c_{\mathrm{O}}$ concentration de l'espece élec- troactive dans l'électrolyte $\left[\mathrm{mol} \mathrm{m}^{-3}\right], A_{2}$ : aire spécifique par unité de volume $\left[\mathrm{m}^{2} \mathrm{~m}^{-3}\right.$ ou $\left.\mathrm{m}^{-1}\right], v$ : vitesse moyenne de l'électrolyte $\left[\mathrm{ms}^{-1}\right], L$ : longueur de l'électrode volumique dans le sens du flux [m]: $Q_{Y}$ : débit volumique de l'électrolyte $\left[\mathrm{m}^{3} \mathrm{~s}^{-1}\right]$, Sh: nombre adimensionnel de Sherwood: Re: nombre adimensionnel de Reynold.

[2] F. Coeuret, A. Storck, 'Eléments de Génie Electrochimique', Lavoisier, Paris, 1984

[3] (Ni): Sorapec, 192 Av. Carnot, F-94124 Fontenay-sous-Bois; (PU): Eltech, 18 Chemin Aulx, CH-1228 Plan-les-Ouates; (RVC): Energy Research and Generation 900 Stanford Avenue, Oakland, Ca. 94608. USA.

[4] S. Langlois, F. Couret, J. Appl. Electrochem. 1989, 19, 43.

[5] R.E. Sioda, J. Appl. Electrochem. 1978, \&, 297.

[6] Ch. Legrand, L.L. Miller, J. Electromal. Chem. 1981, 117, 267.

[7] T. Nagaoka, T. Yoshino, Anal. Chem. 1986, $58,1037$.
Chimia 46 (1992) 155-158

(C) Schweiz. Chemiker-Verband; ISSN 0009-4293

\title{
Complexes of Copper with a Flexible Bis-benzimidazole Ligand
}

\author{
Gérald Bernardinelliª), Anita Kübel-Pollak ${ }^{b}$ ), Stephane Rüttimann ${ }^{b}$ ), and Alan \\ F. Williams $\left.{ }^{b}\right)^{*}$
}

Abstract. The flexible bidentate ligand 1,3-bis(benzimidazol-2-yl)propane, $\mathrm{L}^{3}$, and its $N$-methylated derivative $\mathrm{L}^{4}$, form complexes with $\mathrm{Cu}^{\mathrm{I}}$ and $\mathrm{Cu}^{\mathrm{II}}$. The $\mathrm{X}$-ray crystal structure of $\left[\mathrm{Cu}\left(\mathrm{L}^{4}\right)(\mathrm{MeCN})\right]\left(\mathrm{PF}_{6}\right)(1)$ shows a trigonal coordination of the $\mathrm{Cu}^{1}$ with the eight-membered chelate ring adopting a half-chair conformation. With $\mathrm{Cu}^{\mathrm{Il}}$ in $\mathrm{EtOH}$ $\mathrm{L}^{3}$ forms dimeric $\left[\left(\mathrm{L}^{3}\right) \mathrm{Cu}(\mu-\mathrm{EtO})_{2} \mathrm{Cu}\left(\mathrm{L}^{3}\right)\right]\left(\mathrm{ClO}_{4}\right)_{2} \cdot 2 \mathrm{EtOH}(2)$ whose X-ray crystal structure shows $\mathrm{Cu}^{1 \mathrm{ll}}$ in a distorted square-planar environment with one bidentate ligand and two bridging ethoxides. The chelate ring now has a boat-chair conformation which forms a hydrophobic pocket around the metal.

\section{Introduction}

The formation of polynuclear complexes with unusual structural features such as double helices [1], triple helices [2], or knots [3] is a subject of current interest in coordination chemistry. Some years ago [4], we showed that the ligand 2,6-bis(1-methylbenzimidazol-2-yl) pyridine, $\mathrm{L}^{\mathrm{l}}$, forms with $\mathrm{Cu}^{\mathrm{l}}$ a double helical- dinuclear complex $\left[\mathrm{Cu}_{2}\left(\mathrm{~L}^{\mathrm{J}}\right)_{2}\right]^{2+}$, in which $\mathrm{L}^{1}$ acts as a bis-monodentate ligand, wrapping around the $\mathrm{Cu}-\mathrm{Cu}$ axis in such a way as to give a linear coordination of the $\mathrm{Cu}$ atom. The complex shows a weak bridging interaction due to the pyridines, and a strong stacking interaction between benzimidazoles in the two strands. If the pyridine of $L^{1}$ is replaced by a $P h$ group to give 1,3-bis(1-methylbenzimidazol-2-yl)ben- zene, $\mathrm{L}^{2}$, reaction with $\mathrm{Cu}^{1}$ also affords a dinuclear complex $\left[\mathrm{Cu}_{2}\left(\mathrm{~L}^{2}\right)_{2}\right]^{2+}[5]$, in which the $\mathrm{Cu}$-atom is still linearly coordinated, but the complex is now centrosymmetric, with the ligand adopting a different conformation in which a stacking interaction between the bridging $\mathrm{Ph}$ groups is possible. $\left[\mathrm{Cu}_{2}\left(\mathrm{~L}^{2}\right)_{2}\right]^{2+}$ may be regarded as a conformer of $\left[\mathrm{Cu}_{2}\left(\mathrm{~L}^{1}\right)_{2}\right]^{2+}$, since the two structures may be interconverted simply by twisting about $\mathrm{Cu}-\mathrm{N}$ and benzimidazole-Ph or benzimidazole-pyridine bonds. The double-helical structure of $\left[\mathrm{Cu}_{2}\left(\mathrm{~L}^{1}\right)_{2}\right]^{2+}$ is not possible for $\left[\mathrm{Cu}_{2}\left(\mathrm{~L}^{2}\right)_{2}\right]^{2+}$, since it would result in unacceptably short $\mathrm{Cu}-\mathrm{H}$ distances; it was, therefore, of interest to study the more flexible ligand 1,3-bis(benzimidazol-2yl)propane, $\mathrm{L}^{3}$, and its $N$-methylated derivative $\mathrm{L}^{4}$, which maintain the three $\mathrm{C}$ atom spacer between the benzimidazoles. but give two additional torsional angles of freedom. In this paper, we present the $X$ ray crystal structures of complexes of $\mathrm{L}^{3}$ and $\mathrm{L}^{4}$ with $\mathrm{Cu}^{\mathrm{II}}$ and $\mathrm{Cu}^{1}$, respectively.

\footnotetext{
*Correspondence: Dr. A.F. Williams ${ }^{b}$ )

a) Laboratoire de Cristallographie aux Rayons- $X$ 24, quai Emest-Ansermet $\mathrm{CH}-1211$ Genève 4

b) Département de Chimie Minérale. Analytique et Appliquée 30, quai Ernest-Ansermet $\mathrm{CH}-1211$ Geneve 4
} 


\subsection{Réduction de $\mathrm{Ni}^{+2}$ en présence de complexants}

La réduction électrochimique de $\mathrm{Ni}^{+2}$ complexé par divers acides carboxyliques a été étudiée dans une cellule à cathode volumique de type PU 20 ppi. L'aire cathodique totale était de $0,26 \mathrm{~m}^{2}$ pour un volume de réacteur de $1,910^{-3} \mathrm{~m}^{3}$, ce qui correspond à un rapport aire cathodique/ volume du réacteur de $140 \mathrm{~m}^{-1}$. L'électrolyte est une solution $0,1 \mathrm{M}$ de $\mathrm{Na}_{2} \mathrm{SO}_{4}$ à $\mathrm{pH}$ 6 , contenant environ $100 \mathrm{ppm}$ de $\mathrm{Ni}^{+2}$ et $1 \%$ de divers acides carboxyliques. La vitesse linéaire de l'électrolyte percolant les électrodes est de $8 \cdot 10^{-3} \mathrm{~m} \mathrm{~s}^{-1}$. Une bonne agitation est assurée par de l'air introduit en bas de la cellule. Les résultats obtenus sont présentés sur la fig 7. On constate qu'en prolongeant la durée de la réduction, on peut atteindre une concentration en $\mathrm{Ni}^{+2}$ inférieure à $2 \mathrm{ppm}$ en pré- sence de tous les acides testés, à l'exception de l'acide citrique. La spéciation du Ni en présence d'acide citrique est actuellement étudiée par polarographie et au moyen d'une électrode spécifique.

Une partie de ce travail a été subventionnée par la Commission pour l'encouragement de la recherche scientifique (crédit CERS No. 1762.1).

Reçu le 20 janvier 1992

[1] Nomenclature: $I$ courant limite [A], $n$ : nombre d'électrons échangés, $F$ : constante de Faraday $\left[\mathrm{A} \mathrm{s}^{-1}\right], A$ : aire de l'électrode $\left[\mathrm{m}^{2}\right], K_{\mathrm{d}}$ coefficient de transfert de matière $\left[\mathrm{ms}^{-1}\right], c_{\mathrm{O}}$ concentration de l'espece élec- troactive dans l'électrolyte $\left[\mathrm{mol} \mathrm{m}^{-3}\right], A_{2}$ : aire spécifique par unité de volume $\left[\mathrm{m}^{2} \mathrm{~m}^{-3}\right.$ ou $\left.\mathrm{m}^{-1}\right], v$ : vitesse moyenne de l'électrolyte $\left[\mathrm{ms}^{-1}\right], L$ : longueur de l'électrode volumique dans le sens du flux [m]: $Q_{Y}$ : débit volumique de l'électrolyte $\left[\mathrm{m}^{3} \mathrm{~s}^{-1}\right]$, Sh: nombre adimensionnel de Sherwood: Re: nombre adimensionnel de Reynold.

[2] F. Cœuret, A. Storck, 'Eléments de Génie Electrochimique', Lavoisier, Paris, 1984

[3] (Ni): Sorapec, 192 Av. Carnot, F-94124 Fontenay-sous-Bois; (PU): Eltech, 18 Chemin Aulx, CH-1228 Plan-les-Ouates; (RVC): Energy Research and Generation 900 Stanford Avenue, Oakland, Ca. 94608. USA.

[4] S. Langlois, F. Couret, J. Appl. Electrochem. 1989, 19, 43.

[5] R.E. Sioda, J. Appl. Electrochem. 1978, \&, 297.

[6] Ch. Legrand, L.L. Miller, J. Electromal. Chem. 1981, 117, 267.

[7] T. Nagaoka, T. Yoshino, Anal. Chem. 1986, $58,1037$.
Chimia 46 (1992) 155-158

(C) Schweiz. Chemiker-Verband; ISSN 0009-4293

\title{
Complexes of Copper with a Flexible Bis-benzimidazole Ligand
}

\author{
Gérald Bernardinelliª), Anita Kübel-Pollak ${ }^{b}$ ), Stephane Rüttimann ${ }^{b}$ ), and Alan \\ F. Williams $\left.{ }^{b}\right)^{*}$
}

Abstract. The flexible bidentate ligand 1,3-bis(benzimidazol-2-yl)propane, $\mathrm{L}^{3}$, and its $N$-methylated derivative $\mathrm{L}^{4}$, form complexes with $\mathrm{Cu}^{\mathrm{I}}$ and $\mathrm{Cu}^{\mathrm{II}}$. The $\mathrm{X}$-ray crystal structure of $\left[\mathrm{Cu}\left(\mathrm{L}^{4}\right)(\mathrm{MeCN})\right]\left(\mathrm{PF}_{6}\right)(1)$ shows a trigonal coordination of the $\mathrm{Cu}^{1}$ with the eight-membered chelate ring adopting a half-chair conformation. With $\mathrm{Cu}^{\mathrm{Il}}$ in $\mathrm{EtOH}$ $\mathrm{L}^{3}$ forms dimeric $\left[\left(\mathrm{L}^{3}\right) \mathrm{Cu}(\mu-\mathrm{EtO})_{2} \mathrm{Cu}\left(\mathrm{L}^{3}\right)\right]\left(\mathrm{ClO}_{4}\right)_{2} \cdot 2 \mathrm{EtOH}(2)$ whose X-ray crystal structure shows $\mathrm{Cu}^{1 \mathrm{ll}}$ in a distorted square-planar environment with one bidentate ligand and two bridging ethoxides. The chelate ring now has a boat-chair conformation which forms a hydrophobic pocket around the metal.

\section{Introduction}

The formation of polynuclear complexes with unusual structural features such as double helices [1], triple helices [2], or knots [3] is a subject of current interest in coordination chemistry. Some years ago [4], we showed that the ligand 2,6-bis(1-methylbenzimidazol-2-yl) pyridine, $\mathrm{L}^{\mathrm{l}}$, forms with $\mathrm{Cu}^{\mathrm{l}}$ a double helical- dinuclear complex $\left[\mathrm{Cu}_{2}\left(\mathrm{~L}^{\mathrm{J}}\right)_{2}\right]^{2+}$, in which $\mathrm{L}^{1}$ acts as a bis-monodentate ligand, wrapping around the $\mathrm{Cu}-\mathrm{Cu}$ axis in such a way as to give a linear coordination of the $\mathrm{Cu}$ atom. The complex shows a weak bridging interaction due to the pyridines, and a strong stacking interaction between benzimidazoles in the two strands. If the pyridine of $L^{1}$ is replaced by a $P h$ group to give 1,3-bis(1-methylbenzimidazol-2-yl)ben- zene, $\mathrm{L}^{2}$, reaction with $\mathrm{Cu}^{1}$ also affords a dinuclear complex $\left[\mathrm{Cu}_{2}\left(\mathrm{~L}^{2}\right)_{2}\right]^{2+}[5]$, in which the $\mathrm{Cu}$-atom is still linearly coordinated, but the complex is now centrosymmetric, with the ligand adopting a different conformation in which a stacking interaction between the bridging $\mathrm{Ph}$ groups is possible. $\left[\mathrm{Cu}_{2}\left(\mathrm{~L}^{2}\right)_{2}\right]^{2+}$ may be regarded as a conformer of $\left[\mathrm{Cu}_{2}\left(\mathrm{~L}^{1}\right)_{2}\right]^{2+}$, since the two structures may be interconverted simply by twisting about $\mathrm{Cu}-\mathrm{N}$ and benzimidazole-Ph or benzimidazole-pyridine bonds. The double-helical structure of $\left[\mathrm{Cu}_{2}\left(\mathrm{~L}^{1}\right)_{2}\right]^{2+}$ is not possible for $\left[\mathrm{Cu}_{2}\left(\mathrm{~L}^{2}\right)_{2}\right]^{2+}$, since it would result in unacceptably short $\mathrm{Cu}-\mathrm{H}$ distances; it was, therefore, of interest to study the more flexible ligand 1,3-bis(benzimidazol-2yl)propane, $\mathrm{L}^{3}$, and its $N$-methylated derivative $\mathrm{L}^{4}$, which maintain the three $\mathrm{C}$ atom spacer between the benzimidazoles. but give two additional torsional angles of freedom. In this paper, we present the $X$ ray crystal structures of complexes of $\mathrm{L}^{3}$ and $\mathrm{L}^{4}$ with $\mathrm{Cu}^{\mathrm{II}}$ and $\mathrm{Cu}^{1}$, respectively.

\footnotetext{
*Correspondence: Dr. A.F. Williams ${ }^{b}$ )

a) Laboratoire de Cristallographie aux Rayons- $X$ 24, quai Emest-Ansermet $\mathrm{CH}-1211$ Genève 4

b) Département de Chimie Minérale. Analytique et Appliquée 30, quai Ernest-Ansermet $\mathrm{CH}-1211$ Geneve 4
} 
<smiles>Cn1c(-c2cccc(-c3nc4ccccc4n3C)n2)nc2ccccc21</smiles>

$L^{1}$<smiles>[R]n1c(CCCc2nc3ccccc3n2[R])nc2ccccc21</smiles><smiles>Cn1c(-c2cccc(-c3nc4ccccc4n3C)c2)nc2ccccc21</smiles>

$L^{2}$
$R=H \quad L^{3}$

$R=\mathrm{CH}_{3} L^{4}$

\section{Results}

Synthesis. The ligand $\mathrm{L}^{3}$ is obtained in good yield from 1,3-propane-dicarboxylic acid and 1,2 diaminobenzene using a modified Phillips reaction [6], and may readily be methylated to give $L^{4}[5]$. $L^{4}$ was used for reactions with $\mathrm{Cu}^{1}$ to avoid oxidation catalyzed by the slightly acidic imidazole protons of complexes of $\mathrm{L}^{3}$. The colorless complex $\left[\mathrm{Cu}\left(\mathrm{L}^{4}\right)\left(\mathrm{Me}_{3} \mathrm{CN}\right)\right]$ $\left(\mathrm{PF}_{6}\right), 1$, was obtained by treatment of $\left[\mathrm{Cu}(\mathrm{MeCN})_{4}\right]\left(\mathrm{PF}_{6}\right)$ in acetonitrile solution with a solution of $\mathrm{L}^{4}$ in $\mathrm{CH}_{2} \mathrm{Cl}_{2}$. Reaction of $\mathrm{L}^{3}$ with copper(II) perchlorate in ethanol afforded low yields (typically $30 \%$ ) of $\left[\left(\mathrm{L}^{3}\right) \mathrm{Cu}(\mu-\mathrm{EtO})_{2} \mathrm{Cu}\left(\mathrm{L}^{3}\right)\right]\left(\mathrm{ClO}_{4}\right)_{2}$.
Fig. 1. ORTEP [14] views of $\left[\mathrm{Cu}\left(\mathrm{L}^{4}\right)(\mathrm{MeCN})\right]^{+}$. a) Approximately perpendicular to the ligand plane. Bond distances $\mathrm{Cu}-\mathrm{N}(1)$ 1.960(7), $\mathrm{Cu}-\mathrm{N}(3) \quad 1.977(5), \quad \mathrm{Cu}-\mathrm{N}(01)$ 1.912(9) $\AA$; bond angles $\mathrm{N}(1)-\mathrm{Cu}-$ $\mathrm{N}(3) 118.1(3)^{\circ}, \mathrm{N}(1)-\mathrm{Cu}-\mathrm{N}(01)$ $121.6(3)^{\circ}, \mathrm{N}(3)-\mathrm{Cu}-\mathrm{N}(01) 120.0(3)^{\circ}$. b) View approximately along the pseudo twofold axis, showing the halfchair conformation of the chelate ring (thick bonds).
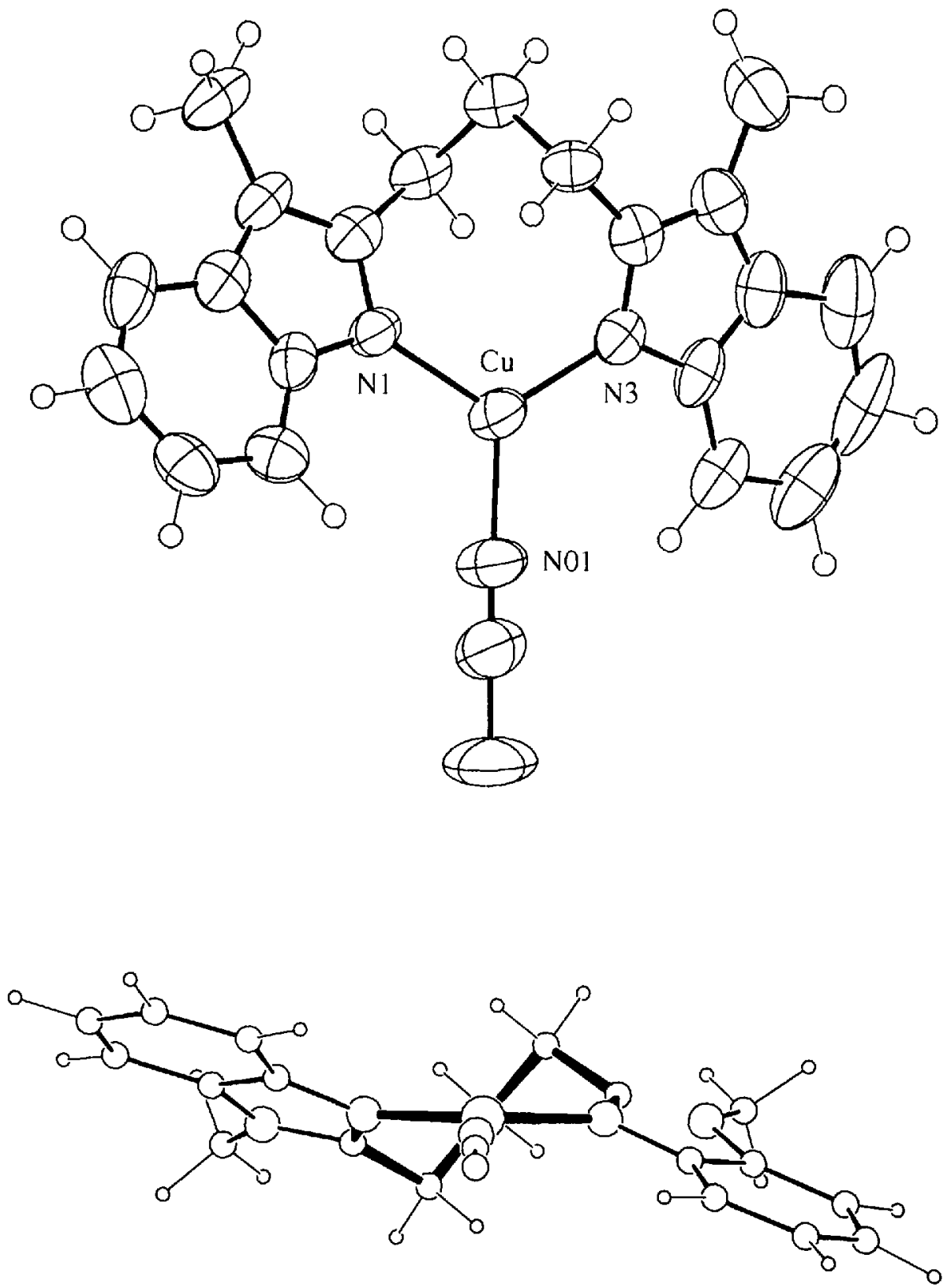
2EtOH, 2, as a brown solid which could be recrystallized from $\mathrm{MeCN} / \mathrm{EtOH}$.

Structure of $\left[\mathrm{Cu}\left(L^{4}\right)(\mathrm{MeCN})\right]\left(P F_{6}\right)(\mathbf{1})$. The structure of the cation $\left[\mathrm{Cu}\left(\mathrm{L}^{4}\right)(\mathrm{MeCN})\right]^{+}$Fig. 1, shows that $\mathrm{L}^{4}$ does not form a dinuclear $\mathrm{Cu}^{\mathrm{I}}$ complex as do $L^{\prime}$ and $L^{2}$, presumably since the flexibility of the ligand allows the formation of the entropically more favorable mononuclear complex. The coordination geometry of the $\mathrm{Cu}$-atom is almost ideal trigonal with a bite angle for the chelate ligand of $118.1(3)^{\circ}$. Bond lengths and angles show no features of particular interest. The eightmembered chelate ring has a half-chair conformation with a non-crystallographic two-fold symmetry axis passing through the $\mathrm{Cu}$-atom and the central atom of the propane bridge $\left(\Delta C_{2}=0.019(2)[7]\right)$. The $\mathrm{Cu}$-atom lies in the mean plane of the ligand [8], and the total puckering amplitude $Q_{\mathrm{T}}=1.256(8) \AA$. The benzimidazoles occupy quasi-equatorial positions with an angle of $145.9(2)^{\circ}$ between their leastsquares planes. The crystal packing shows alternate layers of cations and $\mathrm{PF}_{6}{ }^{-}$anions, with stacking interactions between benzimidazoles of different cations located on either side of a centre of symmetry (interplane distance $3.55 \AA$ ).

Structure of $\left[\left(\mathrm{L}^{3}\right) \mathrm{Cu}(\mu-E t O)_{2} \mathrm{Cu}\left(\mathrm{L}^{3}\right)\right]$ $\left(\mathrm{ClO}_{4}\right)_{2} \cdot 2 \mathrm{EtOH}(2)$. The formation of a brown crystalline product from the green solution of $\mathrm{L}^{3}$ and $\mathrm{Cu}^{\mathrm{II}}$, albeit in low yield, was surprising, and prompted the determination of the crystal structure of this compound, which was revealed to be a di- $\mu-$ EtO dimer (Fig. 2), with a centre of symmetry between the two $\mathrm{Cu}^{\mathrm{II}}$-atoms. The coordination of the $\mathrm{Cu}$-atom is distorted square-planar, with two bridging $\mathrm{EtO}^{-}$anions and a $\mathrm{Cu}-\mathrm{Cu}$ ' distance of $2.979(2) \AA$. The $\mathrm{Cu}-\mathrm{N}$ bond distances are identical within experimental errror to those observed for 1 , but the bite angle of the chelate ligand is $88.5(3)^{\circ}, 30^{\circ}$ less than that observed in 1 . This decrease results in a change in chelate ring conformation (Fig. 3), the eight-membered ring now adopting a stable boat-chair conformation [9] with the $\mathrm{Cu}$-atom as the prow of the boat. There is a non-crystallographic mirror plane $\left(\Delta C_{s}=0.020(2)\right.$ [7]) passing through the $\mathrm{Cu}$-atom and the central atom of the propane bridge. The $\mathrm{Cu}$-atom is now the atom which shows the greatest deviation $(0.948(4) \AA)$ from the mean plane of the chelate ring although the total puckering amplitude $\left(Q_{T}=1.365(13) \AA\right)$ is only slightly greater than for 1 . The benzimidazoles are syn-disposed in quasi-axial positions, with an angle of $105.5(3)^{\circ}$ between their mean planes. The presence of the benzimidazoles requires two of the tor-

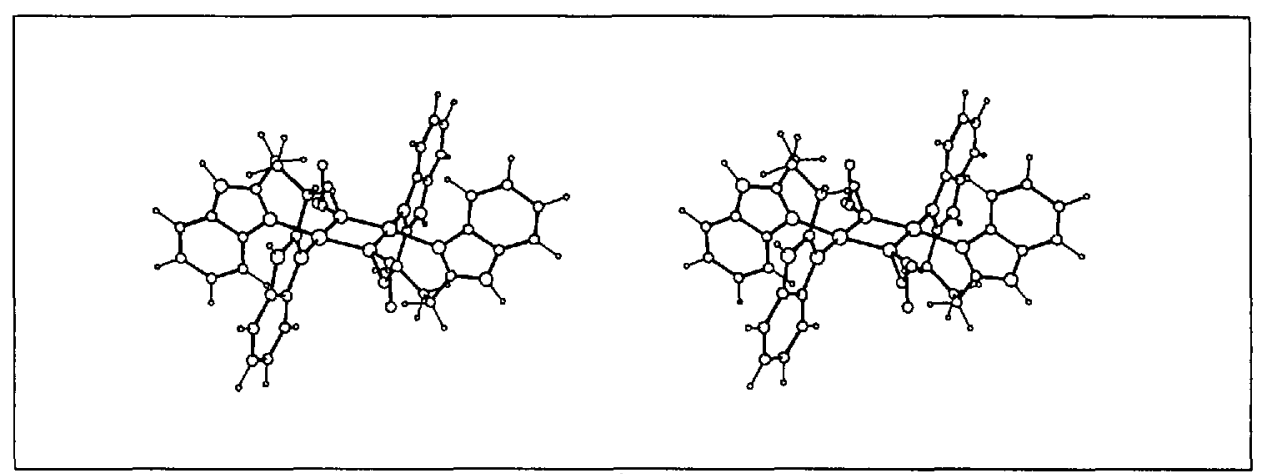

Fig. 2. ORTEP [14] stereoview of the cation $\left[\left(L^{3}\right) \mathrm{Cu}(\mu-\mathrm{EtO})_{2} \mathrm{Cu}\left(L^{3}\right)\right]^{2+}$

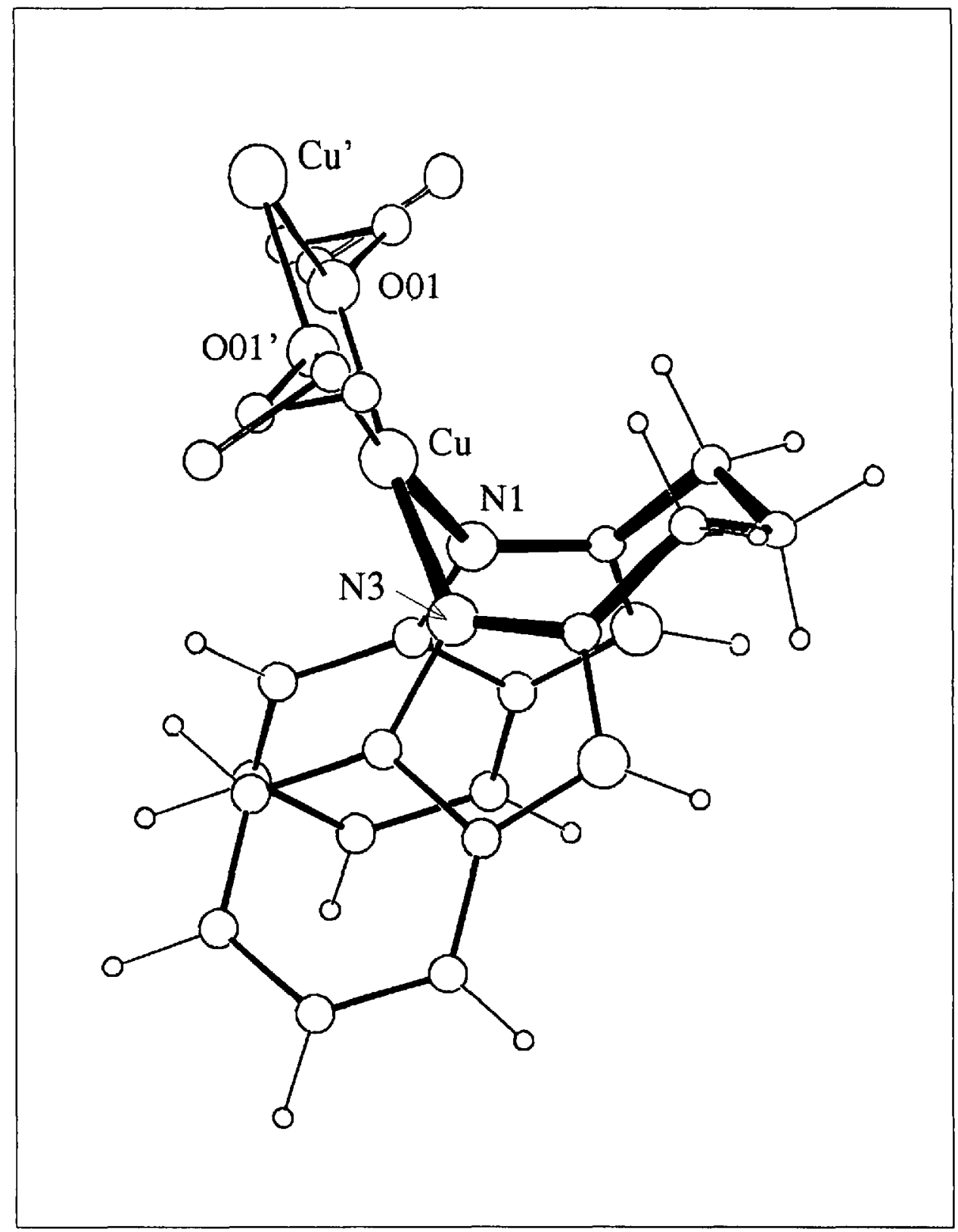

Fig. 3. Partial view of the cation $\left[\left(L^{3}\right) \mathrm{Cu}(\mu-E t O)_{2} \mathrm{Cu}\left(L^{3}\right)\right]^{2+}$ showing the boat-chair conformation of the chelate ring (thick bonds). Bond distances $\mathrm{Cu}-\mathrm{N}(1) 1.973(8), \mathrm{Cu}-\mathrm{N}(3) 1.969(8), \mathrm{Cu}-\mathrm{O}(01)$ $1.909(6), \mathrm{Cu}-\mathrm{O}\left(01^{\prime}\right) 1.912(7)$; bond angles $\mathrm{N}(1)-\mathrm{Cu}-\mathrm{N}(3) 88.5(3)^{\circ}, \mathrm{N}(1)-\mathrm{Cu}-\mathrm{O}\left(01^{\prime}\right) 173.1(3)^{\circ}$, $\mathrm{N}(1)-\mathrm{Cu}-\mathrm{O}(01) 96.5(3)^{\circ}, \mathrm{N}(3)-\mathrm{Cu}-\mathrm{O}\left(01^{\prime}\right) 97.2(3)^{\circ}, \mathrm{N}(3)-\mathrm{Cu}-\mathrm{O}(01) 173.1(4)^{\circ}, \mathrm{O}(01)-\mathrm{Cu}-\mathrm{O}\left(01^{\prime}\right)$ $77.6(3)^{\circ}$.

sion angles to be close to zero, and consequently flattens the boat moiety of the cycle.

The coordinated $\mathrm{EtO}^{-}$anions are disordered about a two-fold axis passing through the $\mathrm{O}$-atom and a point on the $\mathrm{C}-\mathrm{C}$ bond, and were refined with equal population parameters. The observation of EtO- anions was surprising since the only base present in solution during the synthesis difficult to deprotonate than $\mathrm{H}_{2} \mathrm{O}$ (present was the free ligand, and ethanol is more 
from the $\mathrm{H}_{2} \mathrm{O}$ of crystallization of the $\mathrm{Cu}$ perchlorate). Furthermore, benzimidazoles coordinated to $\mathrm{Cu}^{\mathrm{II}}$-atom are deprotonated even by weak bases [10], and a deprotonation of the ligand might have been expected rather than the formation of a hydroxo complex. It is, therefore, necessary to seek some effect which will stabilize the ethoxy bridge, and examination of a space-filling representation of the structure of $\mathbf{2}$ suggests that the benzimidazoles and the aliphatic bridging chain form a hydrophobic pocket around the $\mathrm{Cu}_{2} \mathrm{O}_{2}$ core, and thus the coordination of an $\mathrm{EtO}$ group might be more favorable than a $\mathrm{OH}$ group.

The non-coordinated EtOH molecule is also disordered, and was refined as two separate molecules each with a population parameter of $50 \%$. They form $\mathrm{H}$-bonds to a N-H group of a benzimidazole $(\mathrm{N} \cdots \mathrm{O}$ distances 2.76(3) and 2.73(3) $\AA$ ). The $\mathrm{ClO}_{4}^{-}$ anion is not disordered, but forms a $\mathrm{H}$ bond with the benzimidazole $\mathrm{N}-\mathrm{H}$ group which is not bound to the $\mathrm{EtOH}(\mathrm{O} \cdots \mathrm{N}$ distance $2.91(2) \AA$ )

\section{Conclusion}

The flexibility of $\mathrm{L}^{3}$ and $\mathrm{L}^{4}$ allows them to act as bidentate ligands rather than as bis-monodentate ligands as observed for $\mathrm{L}^{1}$ and $\mathrm{L}^{2}$. Although, by tradition, coordination chemists have tended to study ligands forming five- or six-membered chelate rings, the two structures presented here show that larger rings may readily be formed. The very flexibility of the chelate ring allows the bite angle to vary by $30^{\circ}$ while maintaining the same $\mathrm{Cu}-\mathrm{N}$ bond distances. When the bite angle of the chelate ring is reduced, the metal ion puckers up out of the mean plane of the chelate ring, which then forms a hydrophobic region around the metal ion, whereas, if the metal ion lies in the plane of the chelate ring, the non-polar regions of the ligand lie away from the metal. This possibility of using a large chelate ring to generate a hydrophobic region around a metal ion is currently being investigated in our laboratories.

\section{Experimental}

Synthesis of 1,3-Bis(benzimidazol-2-yl)propane (L)

A mixture of $6.6 \mathrm{~g}(0.05 \mathrm{~mol})$ of 1,3-propanedicarboxylic acid, $11.9 \mathrm{~g}(0.11 \mathrm{~mol})$ benzene-1,2diamine and $100 \mathrm{ml} \mathrm{H}_{3} \mathrm{PO}_{4}(85 \%)$ were heated at $180^{\circ}$ with mechanical stirring for $3 \mathrm{~h}$. After cooling, the dark blue soln. was poured into $2 \mathrm{I}$ of $\mathrm{H}_{2} \mathrm{O}$, and the resulting precipitate filtered and suspended in $500 \mathrm{ml}$ of aq. $\mathrm{NH}_{3}(12 \%)$. The precipitate was treated with activated carbon in $\mathrm{MeOH}$, and recrystallized from $\mathrm{MeOH} / \mathrm{H}_{2} \mathrm{O}$, to give $12.8 \mathrm{~g}$ of ligand $\mathrm{L}^{3}(92 \%)$. 'H-NMR (400 MHz, ( $\left.\mathrm{D}_{6}\right) \mathrm{DMSO}$ ): 12.1 (br. $\left.s, 2 \mathrm{H}\right) ; 7.46(m, 4$ H); $7.10(m, 4 \mathrm{H}) ; 2.91\left(t, 4,{ }^{3} J=7.5,4 \mathrm{H}\right) ; 2.29(q$, $3 J=7.5,2 \mathrm{H})$. MS: $277\left(23,[M+H]^{+}\right), 145(100)$, $132(96), 92(23)$.

Synthesis of 1,3-Bis(1-methylbenzimidazol-2 yl)propane $\left(L^{4}\right)$

$\mathrm{L}^{3}$ was methylated as described in $[5][10]$, and recrystallized from $\mathrm{MeCN}$. M.p. 172-175 ${ }^{1} \mathrm{H}-\mathrm{NMR}\left(200 \mathrm{MHz}, \mathrm{CDCl}_{3}\right) ; 7.68(m, 4 \mathrm{H}) ; 7.23$ $(m, 4 \mathrm{H}) ; 3.72(s, 6 \mathrm{H}) ; 3.08(t, 4 \mathrm{H}) ; 2.50(q, 2 \mathrm{H})$. MS: $305\left(8,[M+H]^{+}\right), 159(100), 146(80), 131$ (51), $104(19)$

Synthesis of 1,3-Bis(I-methylbenzimidazol-2yl)propane(acetonitrile) copper(I) Hexafluorophosphate. $\left[\mathrm{Cu}\left(\mathrm{L}^{4}\right)(\mathrm{MeCN})\right]\left(\mathrm{PF}_{6}\right)(\mathbf{1})$

$\left[\mathrm{Cu}(\mathrm{MeCN})_{4}\right]\left(\mathrm{PF}_{6}\right)[12](0.246 \mathrm{~g}, 0.66 \mathrm{mmol})$ was dissolved in $15 \mathrm{ml}$ of degassed MeCN under $\mathrm{N}_{2} .0 .200 \mathrm{~g}(0.66 \mathrm{mmol})$ of $\mathrm{L}^{4}$ dissolved in $10 \mathrm{ml}$ $\mathrm{CH}_{2} \mathrm{Cl}_{2}$ under $\mathrm{N}_{2}$ were added, and the $\mathrm{CH}_{2} \mathrm{Cl}_{2}$ evaporated under vacuum to avoid precipitation of the unreacted $\mathrm{Cu}$ salt. Diffusion of ether into the soln. under $\mathrm{N}_{2}$ gave colorless crystals of quality suitable for $\mathrm{X}$-ray diffraction. Analysis: found: C 46.6, H 4.4, N 12.75; calc.: C 45.5, $\mathrm{H}$ $4.5 \%, \mathrm{~N} 12.6$.

Synthesis of Di- $\mu$-ethoxy-di-1,3-bis(benzimidazol-2-yl)propane-dicopper(II) perchlorate Diethanol Solvate, $\left[\left(L^{3}\right) \mathrm{Cu}(\mu-\mathrm{EtO})_{2} \mathrm{Cu}\left(\mathrm{L}^{3}\right)\right]\left(\mathrm{ClO}_{4}\right)_{2}$ $2 \mathrm{EtOH}(2)$

To a soln. of $\mathrm{L}^{3}(0.138 \mathrm{~g}, 0.5 \mathrm{mmol})$ in abs. $\mathrm{EtOH}$ at $80^{\circ}$, a soln. of $0.186 \mathrm{~g}(0.5 \mathrm{mmol})$ $\mathrm{Cu}\left(\mathrm{ClO}_{4}\right)_{2} \cdot 6 \mathrm{H}_{2} \mathrm{O}$ (Fluka) in $4 \mathrm{ml}$ of abs. EtOH was added and the soln. maintained at $80^{\circ}$ for 12 h. From the violet soln., brown crystals of 2 were deposited slowly. Yields were typically around $30 \%$. Crystals of quality suitable for $\mathrm{X}$-ray diffraction were grown by vapour diffusion of $\mathrm{EtOH}$ into an $\mathrm{MeCN}$ soln. of 2 .

$X$-Ray Crystal Structure Determinations

$\mathrm{Cu}\left(\mathrm{C}_{\mathrm{T} 9} \mathrm{H}_{20} \mathrm{~N}_{4}\right)(\mathrm{MeCN}) \mathrm{PF}_{6}, M_{\mathrm{r}}=554.0$, triclinic, $P l, a=7.537(1), b=12.357(1), c=$ 14.286(2) $\AA, \alpha=65.18(1)^{\circ}, \beta=75.75(1)^{\circ}, \gamma=$ $82.33(1)^{\circ}, V=1169.7(3) \AA^{3}, Z=2, D=1.57$ $\mathrm{g} \cdot \mathrm{cm}^{-3}, \mathrm{Mo}(K \alpha) \lambda=0.71069 \AA, \mu=1.057 \mathrm{~mm}^{-1}$, $F(000)=564.3254$ unique reflections measured at r.t., 2427 observed $\left(\left|F_{0}\right| \geq 4 \sigma\left(F_{0}\right)\right), R=0.068$ using unit weights for 310 variables with all nonhydrogen atoms refined with anisotropic displacement parameters.

$\left[\mathrm{Cu}\left(\mathrm{C}_{17} \mathrm{H}_{16} \mathrm{~N}_{4}\right)(\mathrm{EtO})\right]_{2}\left(\mathrm{ClO}_{4}\right)_{2}(\mathrm{EtOH})_{2}, M_{r}$ $=1062.9$, monoclinic, $P 2, i n, a=9.848(2), b=$ 13.000(2), $c=18.750$ (3) A, $\beta=96.46(1)^{\circ}, V=$ $2385.2(7) \AA^{3}, Z=2, D_{1}=1.48 \mathrm{~g} \cdot \mathrm{cm}^{-3}, \operatorname{Mo}(K \alpha)$, $\lambda=0.71069 \AA, \mu=1.072 \mathrm{~mm}^{-1}, F(000)=1104$. 3749 unique reflections measured, 2170 observed $(\mid F \mathrm{ol} \geq 4 \sigma(F \mathrm{o})), \mathrm{R}=0.074$ using unit weights for 293 variables with all non- $\mathrm{H}$-atoms except the disordered EtOH groups refined with anisotropic displacement parameters.
Structures were solved by direct methods [12], and all other calculations used the XTAL [13] and ORTEP II [14] programs. Full details of the crystal-structure determination will be published elsewhere [15].

Received: January 17,1992

[1] a) J.-M. Lehn, A. Rigault, J. Siegel, J. MacB. Harrowfield, B. Chevrier, D. Moras, Proc. Natl. Acad. Sci. U.S.A. 1987, 84, 2565; b) U. Koert, M.M. Harding, J.-M Lehn, Nature (London) 1990, 346, 339; c) E.C. Constable, M.D. Ward, J. Am. Chem. Soc. 1990, 1/2, 1256; d) E.C. Constable, M.D. Ward, D.A. Tocher, J. Chem. Soc., Dalton Trans. 1991, 1675; e) M. Barley, E.C. Constable, S.A. Corr, R.S. McQueen J.C. Nutkins, M.D. Ward, M.G.B. Drew, ibid. 1988, 2655.

[2] A.F. Williams, C. Piguet, G. Bernardinelli, Angew. Chem. Int. Ed. 1991, 30, 1490.

[3] J.-P. Sauvage, Acc. Chem. Res. 1990, 23, 319.

[4] C. Piguet, G. Bernardinelli, A.F. Williams, Inorg. Chem. 1989, 28, 2920.

[5] S. Ruttimann, C. Piguet, G. Bernardinelli, B. Bocquet, A.F. Williams, J. Am. Chem. Soc., in press.

[6] A.W. Addison, P.J. Burke, J. Heterocycl. Chem. 1981, 18, 803; A.W. Addison, T.N. Rao, C.G. Wahlgren, ibid. 1983, 20, 1481.

[7] M. Nardelli,Acta Cnystallogr., Sect. C 1983 , 39,1141 .

[8] D. Cremer, J.A. Pople, J. Am. Chem. Soc. $1975,97,1354$

[9] J.B. Hendrickson, J. Am. Chem. Soc. 1967, $89,7036$.

[10] C. Piguet, B. Bocquet, E, Muller, A.F. Williams, Helv. Chim. Acta 1989, 72, 323.

[11] G.J. Kubas, Inorg. Synth. 1979, 19, 90.

[12] P. Main, S.J. Fiske. S.E. Hull, L. Lessinger, D. Germain, J.P. Declercq, M.M. Woolfson, 'MULTAN 87', Universities of York, England, and Louvaine-La-Neuve, Belgium, 1987.

[13] S.R. Hall, J.M. Stewart, Eds., 'XTAL 3.0 User's Manual', Universities of Western Australia and Maryland, 1990.

[14] C.K. Johnson, 'ORTEP II', Report ORNL5138, Oak Ridge National Laboratory, Oak Ridge, Tennessee, 1976.

[15] G. Bernardinelli, A. Pollak-Kubel, S. Rüittimann, A. F. Williams, submitted to $Z$. Kristallogr. 